\title{
Informação e conhecimento (ou líquido e sólido): dois estados da mesma matéria?
}

\author{
Information and knowledge (or liquid and solid): two states of the same substance?
}

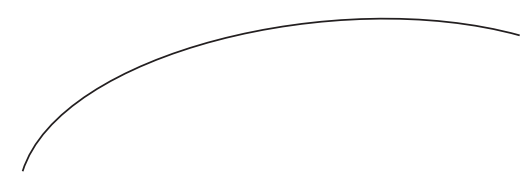

O que há de diferente entre informação e conhecimento? A rapidez com que se produz e reproduz a primeira em detrimento do segundo? A falta de consistência, de testagem de veracidade das informações? A ausência de autoria da informação, sua fugacidade e permanente (des)construção? Ou se trata simplesmente de duas maneiras de ver (ou deixar de ver) o que se deseja?

Em tempos de redes sociais e aplicativos prontamente disponíveis, à mão de qualquer detentor de aparelhos cada vez mais sofisticados, a informação tem tragado o conhecimento. Em frações de segundos, "sabe-se", "comenta-se" e "cria-se" o que se deseja, sem que uma avaliação crítica seja realizada. Todos entendem de tudo. Uma verdadeira panaceia, muitas vezes com adereços de crueldade. Não se pensa mais no que se está produzindo, simplesmente se produz. Não há tempo hábil para pensar. A velocidade e a rapidez com que se produz a "nova" informação tem qualificado o informante. E nessa Babel da informação, nessa liquidez de opiniões desencontradas, o conhecimento e seus "conhecedores" passam a ser coadjuvantes das cenas, saem de moda, se tornam obsoletos - "velhos", por assim dizer.

Conhecer demanda tempo, leitura, imersão no objeto que se deseja aprender. Conhecer é um processo que depende do manuseio das páginas de muitos livros (aqueles completos, na própria acepção da palavra), das incursões em ambientes onde possamos senti-lo e respirálo, nos templos de sua ovação, as bibliotecas. É desbravar, cavar trincheiras, explorar o "desconhecido". É muito mais que um abrir e fechar de olhos (e já "saber" de tudo). Conhecer é o que impulsiona a vida de um verdadeiro cientista.

Nesse sentido, a bandeira empunhada pela Revista Brasileira de Geriatria e Gerontologia é a do conhecimento e sua divulgação. E é por isso que ainda mantemos impressos os números da revista, pelo imenso prazer de folheá-la e de estimular o hábito da leitura. No entanto, e como não podia deixar de ser, também nos penduramos na "cauda do cometa" e nos projetamos pela via láctea da informação, para nós, pautada democraticamente em terreno sólido. Estamos, portanto, online e com nossos hot topics nas principais redes sociais, numa espécie de construção de uma contracorrente viscosa que não se esvai no primeiro acesso de qualquer leitor. Pelo contrário, esperamos que o \#rbgg leve os leitores a refletirem acerca da dualidade conhecimento/informação. 
E por falar em conhecimento e democracia, como de praxe, procuramos de modo equânime distribuí-lo espacialmente em todo o nosso país, assim como em relação às temáticas dos artigos aprovados.

Desejamos, portanto, uma boa leitura a todos, seja ela no telefone celular, no tablet, no computador de mesa ou no portátil, ou de modo tradicional, exercendo o prazer dos sentidos. Afinal, ter a sensação tátil de tocar as folhas de papel com as pontas dos dedos no vai e vem das páginas, sentir o cheiro das folhas brancas com letras negras, ouvir o som regozijante do entrelaçar das páginas e ver em profundidade letras, palavras, frases, orações, subtítulos, títulos, pessoas, pesquisadores, cientistas, instituições e seus "sentimentos" - não há tecnologia que suplante.

Prof. Kenio Lima Editor Associado 